City University of New York (CUNY) CUNY Academic Works

2011

\title{
Who Enters the Foreclosure Process?
}

Eric Doviak

Graduate Center, City University of New York

Sean P. MacDonald

CUNY New York City College of Technology

\section{How does access to this work benefit you? Let us know!}

More information about this work at: https://academicworks.cuny.edu/ny_pubs/157

Discover additional works at: https://academicworks.cuny.edu

This work is made publicly available by the City University of New York (CUNY).

Contact: AcademicWorks@cuny.edu 


\title{
Who Enters the Foreclosure Process?
}

\author{
Eric Doviak* Sean MacDonald ${ }^{\dagger}$
}

\begin{abstract}
Since February 2010, detailed information on every home mortgage default and foreclosure in New York State must be filed with the New York State Banking Department (NYSBD). The data enables us to identify the financial characteristics that make a defaulted borrower more (or less) likely to enter the foreclosure process.

Our analysis of the NYSBD data suggests that borrowers in default who took larger loans are more likely to progress to foreclosure. It also suggests that reducing principal balances may reduce the foreclosure rate, but might have an adverse effect on the mortgage industry.

Given the frequent criticism of the Home Affordable Modification Program (HAMP), it is no surprise that defaulted borrowers whose mortgages were modified via HAMP progress to a lis pendens filing a higher rate than defaulted borrowers without a modification or with a non-HAMP modification. After controlling for delinquency length (and other factors) however, we find that the HAMP program may have been effective in helping defaulted borrowers avoid foreclosure.
\end{abstract}

\section{INTRODUCTION}

Under a state law that was enacted on December 15, 2009, mortgage servicers must send a "preforeclosure filing" (PFF) notice to delinquent borrowers at least 90 days prior to filing for foreclosure on a primary residence in the State of New York. The notice informs homeowners that their loan is in default, lists the amount necessary to cure the default and lists measures that they can take to avoid foreclosure, such as negotiating a loan modification with their lender and consulting with a non-profit housing counselor (New York State Banking Department, 2009).

Since February 13, 2010, mortgage servicers are also required to file the notices with the New York State Banking Department (NYSBD), which collected an extraordinary level of detail on the loans. Among the many data fields collected are: the property address, the names of the borrowers, the current monthly payment, the delinquent contractual payments, the interest rate, whether the loan is a fixed-rate or adjustable-rate mortgage, the date and the amount of the original loan, the lien type, the loan term, whether the loan has been modified or not and whether an investor's approval is necessary to modify the loan. If the loan progresses to a lis pendens filing (i.e. the first step in the foreclosure process - the filing

*Brooklyn College, City University of New York - eric@doviak. net

$\dagger^{\dagger}$ New York City College of Technology, City University of New York - smacdonald@citytech.cuny .edu 
of the complaint), then servicers are also required to follow up on their initial filing with information on the entity filing for foreclosure.

The detail captured in the PFF data makes three forms of analysis possible. First, we can match the defaulted loans to publicly available data on originations from the Home Mortgage Disclosure Act (HMDA). By combining the HMDA and PFF data, we can see which borrowers were more likely to default. Second, we can compare the loans that entered the foreclosure process to those that did not. For reasons described below, we call this the "Short PFF" dataset. Finally, our "Full PFF" dataset allows us to compare defaulted loans across the years in which they were originated.

This paper discusses the findings of our analysis of the Full PFF and Short PFF datasets. We discuss our analysis of the combined HMDA-PFF dataset in a separate paper (Doviak and MacDonald, 2011).

Not surprisingly, the financial characteristics of a loan are the best predictors of progression from default to a lis pendens filing. Larger loan amounts, larger monthly payments and adjustable interest rates all make a defaulted borrower more likely to enter the foreclosure process. Although the PFF data does not contain the loan-to-value ratio, we can surmise that borrowers who took out larger loans were left with less equity (or even negative equity) in his/her home after home prices tumbled during the recent economic and financial crisis. Consequently, borrowers who took out larger loans may have had greater incentive to walk away from the loan and shift the loss onto the lender.

Another shortcoming of the PFF data is that it does not contain information on the borrower's current or past income. Nonetheless, we can surmise that larger monthly payments would make it more difficult for the borrower to remain current on the loan.

All else equal, a higher interest rate also increases the borrower's monthly payments, thus making the loan more difficult to repay. In this regard, it is important to note that mortgages without a fixed interest rate were more likely to progress from default to a lis pendens filing than those with a fixed interest rate. Once again, this is not surprising. When interest rates reset upward, the increasing cost of these adjustable-rate mortgages left borrowers unable to afford the mortgage.

What is surprising is the Home Affordable Modification Program (HAMP) may have been more successful in preventing foreclosure than its critics suggest. Like many other studies, we find that HAMPmodified mortgages progress to a lis pendens filing a higher rate than mortgages in default that were not modified or were modified outside of the HAMP program. The higher rate of progression may be attributable to the longer length of time HAMP-modified mortgages have been delinquent however. After controlling for delinquency length (and other factors), we find that HAMP-modified mortgages were less likely to progress to a lis pendens filing, which indicates that the HAMP program may have been effective in helping defaulted borrowers avoid foreclosure.

Prior to discussing those findings, we will first discuss the literature on mortgage modification and foreclosure prevention in section 2. Then, in section 3, we describe the PFF data in more detail and how we prepared it for analysis.

Section 4 is the heart of this paper. It explores the question of "Who enters the foreclosure process?" by comparing the defaulted loans that did not enter the foreclosure process to those that did. To control for the many different factors that can affect a the probability that a loan will progress from default to foreclosure, section 5 provides a very basic regression analysis that attempts to resolve some of the puzzles that we find in the comparisons and continues to explore the racial and ethnic dimensions of the 
foreclosure crisis.

Section 6 concludes with a discussion of how lenders can use our findings to reduce the losses that they suffer when a loan enters the foreclosure process.

\section{REVIEW OF THE FORECLOSURE PREVENTION LITERATURE}

The subprime mortgage foreclosure crisis, which began in 2006 and escalated rapidly throughout 2007 and 2008, was one of the first indicators of the forthcoming bursting of the nation's housing bubble. It also foreshadowed the onset of the financial and credit crises that unfolded during $2008-2009$, resulting in a persistently high rate of unemployment that contributed to the national wave of foreclosures that began in 2008.

Unemployment alone does not explain the recent surge in defaults and foreclosures however. The character of the loans originated between 2004 and 2008 also played a significant role, so regulators responded by adopting several major loan modification programs. This section provides an overview of loan modification programs adopted since 2008 and discusses their success in stemming the foreclosure crisis.

The primary programs - the Making Home Affordable program ${ }^{1}$, the Home Affordable Modification Program (HAMP) ${ }^{2}$ and the FHA's HOPE for Homeowners Program ${ }^{3}$ - have relied upon the voluntary participation of lenders and servicers. These programs have employed a number of incentives to encourage participants to modify the loans of homeowners at risk of default and foreclosure. Overall, they have reached a relatively small percentage of the borrowers in need because the participation of lenders and loan servicers is voluntary and because many lenders and loan servicers have resisted efforts to persuade them to reduce principal balances.

According to CoreLogic (2011), at the end of the fourth quarter of 2010, approximately 11 million U.S. households - representing an estimated 23 percent of all homes with a mortgage - owed more on their homes than their home was worth. As of May 2011, more than two million borrowers were seriously delinquent on their loans (90 days or more past due), while another two million homeowners were in some stage of the foreclosure process as of May 2011 (RealtyTrac, 2011).

In an effort to avoid such outcomes, the US Treasury Department established HAMP as part of the Making Home Affordable program in October 2009. HAMP aims to modify the principal balance and interest rate on the home mortgages of borrowers who have good repayment histories but are experiencing financial hardship (U.S. Dept. of the Treasury, 2009).

Analysis of the Treasury Department's own published reports on HAMP's performance indicates that, as of June 2011, a total of 772,559 homeowners were participating in active trial modifications or active permanent modifications (U.S. Dept. of the Treasury, 2011). Thus, slightly more than three-quarters of a million distressed homeowners nationwide are or have been assisted by the Making Home Affordable program. More distressing however is the fact that almost half (46.4 percent) of the 1.6 million trial

\footnotetext{
${ }^{1}$ The Making Home Affordable program, which was created under the Emergency Economic Stabilization Act (EESA) of 2009, provided $\$ 29.9$ billion for participating institutions.

${ }^{2}$ The Home Affordable Modification Program (HAMP) is part of the Making Home Affordable program.

${ }^{3}$ The FHA's HOPE for Homeowners Program was enacted under the 2008 Housing and Economic Recovery Act.
} 
modifications started under the Making Home Affordable program were cancelled as of June 2011 (U.S. Dept. of the Treasury, 2011).

These programs may have had some success in reducing the foreclosure rate. According to RealtyTrac (2011), in May 2011, foreclosure filings nationally declined to their lowest level since December 2006, reaching a 53-month low. The decline also reflected a 33 percent decrease from May 2010.

Other programs have been far less successful.

Using its authority to provide mortgage insurance for refinancing the mortgages of borrowers at risk of default and foreclosure, the FHA introduced its HOPE for Homeowners Program in October 2008. Four months after the program began however, the FHA had only received 451 applications and closed a mere 25 loans, far short of the 400,000 homeowners that the program had been expected to help (Naylor, 2009).

While changes were made to attract participation, its prospects are not very bright. One key problem is that participation is voluntary. Lenders do not have to agree to a modification that writes down any portion of the loan's value. A second problem is that the borrowers most in need are the one least like to be served by the program. For example, borrowers with a lower credit score or more erratic payment history must meet more stringent qualifying criteria. Moreover, payment-to-income ratios can run as high as 38 percent (U.S. Office of the Comptroller of the Currency, 2010). Such requirements deter both borrowers and lenders from participating.

More importantly, the continued decline in home values places lenders at risk of holding a loan that is greater than the home's value and thus eliminating the possibility of securitizing the loan. Home prices declined an average of 8.2 percent from first quarter 2010 through first quarter 2011 (Humphries, 2011). The resulting low appraisal values have hindered millions of homeowners - not just those at risk - from refinancing their loans.

From the perspective of a borrower in a negative equity position, shifting losses onto the lender through the foreclosure process may be a regrettable but financially sensible course of action. Consequently, reductions in principal balance may be necessary to avert foreclosure. This was a primary finding of the State Foreclosure Prevention Working Group (SFPWG) ${ }^{4}$, which found that loan modifications involving "significant payment reduction has succeeded in creating more sustainable loan modifications" (2010).

In particular, the SFPWG, which analyzed a longitudinal dataset from nine loan servicers, found that more recent modifications which included significant reductions in principal balance tend to have lower re-default rates than their counterparts. However, modifications with a significant reductions in principal balance represent just 20 percent of the loan modifications that they studied. In most modifications, the loan amount increased as service charges and late payments were rolled into the loan.

To convince the borrower to accept the modification, lenders and servicers preferred to reduce the monthly payment. In the SFPWG's dataset, 89 percent involved a reduction in monthly payments. Of those, the modification reduced the monthly payment by more than 10 percent in 77 percent of cases (State Foreclosure Prevention Working Group, 2010).

\footnotetext{
${ }^{4}$ The State Foreclosure Prevention Working Group, which began publishing findings on mortgage delinquency and loss mitigation trends in early 2008, includes representatives of the attorneys general from twelve states, state bank regulators from three states and the Conference of State Bank Supervisors.
} 
Table 1: Distribution of Pre-Foreclosure Filings by Year of Origination

\begin{tabular}{lrr}
\hline \hline & total & percent \\
\hline $1976-1989$ & 2,502 & $1.3 \%$ \\
$1990-1999$ & 13,692 & $7.3 \%$ \\
2000 & 2,414 & $1.3 \%$ \\
2001 & 4,390 & $2.4 \%$ \\
2002 & 7,470 & $4.0 \%$ \\
2003 & 16,706 & $9.0 \%$ \\
2004 & 18,669 & $10.0 \%$ \\
2005 & 28,506 & $15.3 \%$ \\
2006 & 35,947 & $19.3 \%$ \\
2007 & 31,771 & $17.0 \%$ \\
2008 & 16,019 & $8.6 \%$ \\
2009 & 6,957 & $3.7 \%$ \\
2010 & 1,323 & $0.7 \%$ \\
\hline total & 186,366 & $100.0 \%$ \\
\hline Data: Full PFF \\
\hline \multicolumn{3}{l}{} \\
\hline
\end{tabular}

\section{THE NEW YORK STATE PRE-FORECLOSURE FILING DATA}

As mentioned in the introduction, in February 2010, the New York State Banking Department (NYSBD) began collecting data on home mortgages in default. When the borrower defaults on his/her primary residence, his/her mortgage servicer sends him/her a "pre-foreclosure filing" (PFF) notice and transmits an extraordinary level of detail on the mortgage to the NYSBD. If the borrower does not cure the default within 90 days, the servicer may commence the foreclosure process with a lis pendens filing. If it chooses to do so, it must also inform the NYSBD of the lis pendens filing.

Because the PFF dataset contains information on both defaults and foreclosures, the analysis in this paper compares defaulted loans that did not progress to foreclosure to those that did. Given the 90-day window between the date that the PFF notice was sent and the commencement of foreclosure proceedings, such an analysis requires examination of a subset of the data. We refer to this subset as the "Short PFF" dataset to distinguish it from the "Full PFF" dataset, which contains all of the filings.

This paper also makes reference to the Full PFF dataset because it is useful for comparing defaulted loans by year of origination. For example, table 7 shows that defaulted loans originated between 2004 and 2007 were more likely to be adjustable rate mortgages than loans originated in other years.

Prior to making those comparisons however, we first explain how we prepared the PFF dataset for statistical analysis in subsection 3.1. After providing that explanation, we discuss our comparisons in section 4 and we provide a very basic regression analysis in section 5 . 
Table 2: Rate of Lis Pendens by Month when PFF Letter Sent

\begin{tabular}{lrr|r}
\hline \hline & Lis Pendens & PFF Letters & rate \\
\hline January & 9 & 1,573 & $0.6 \%$ \\
February & 1,745 & 8,171 & $21.4 \%$ \\
March & 1,416 & 12,625 & $11.2 \%$ \\
April & 1,725 & 12,847 & $13.4 \%$ \\
May & 1,807 & 14,135 & $12.8 \%$ \\
June & 1,474 & 27,810 & $5.3 \%$ \\
July & 657 & 20,139 & $3.3 \%$ \\
August & 405 & 16,779 & $2.4 \%$ \\
September & 68 & 13,837 & $0.5 \%$ \\
October & 24 & 15,395 & $0.2 \%$ \\
November & 119 & 13,438 & $0.9 \%$ \\
December & 17 & 27,623 & $0.1 \%$ \\
\hline total & 9,466 & 184,372 & $5.1 \%$ \\
\hline Data: Full PFF & \multicolumn{3}{|l}{} \\
\hline
\end{tabular}

\subsection{Preparing the Data for Analysis}

Prior to performing an analysis of the PFF data, we had to remove duplicate filings because servicers who missed the three-business day deadline or submitted incorrect information would "re-file" the loan. Some servicers also submitted one filing for each borrower on the loan.

The duplicates were fairly easy to identify however, because servicers almost always included their loan numbers with the filing, so the combination of the servicer's identity and the loan number enabled us to uniquely identify each loan ${ }^{5}$. In cases where a servicer submitted one filing for each borrower, we compared the borrower's first and last name to the names of other borrowers on the loan to see if there was a co-applicant or not.

Because servicers re-filed a loan to correct mistakes, we assumed that the filing which was submitted last contained the correct information. However if one of the duplicates contained information on a lis pendens filing, we retained that information.

Using this method, we found a total of 214,705 unique loans and 33,859 duplicates in the PFF dataset. From there, we removed records that contained obvious errors (e.g. loans that were originated in the future) and records of 90-day letters that were not mailed in the year 2010. This reduced the PFF dataset to 211,962 clean records.

To ensure comparability across loans, we chose to focus on first-lien mortgages. This reduced the PFF dataset to 186,366 records, but it was a necessary step because a first-lien mortgage is very different from a home equity line of credit (HELOC). The former is frequently taken for the purpose of purchasing a home, while the latter is often used for home improvement.

\footnotetext{
${ }^{5}$ In cases where the servicer did not include a loan number, we used the property address instead of the loan number.
} 
Table 3: Lis Pendens Filing by Loan Amount (in thousands)

\begin{tabular}{lrr|r}
\hline \hline & no lis pendens & lis pendens & percent \\
\hline under 50 & $6.3 \%$ & $3.4 \%$ & $5.9 \%$ \\
50 to 99 & $19.7 \%$ & $14.1 \%$ & $18.8 \%$ \\
100 to 249 & $29.9 \%$ & $26.2 \%$ & $29.3 \%$ \\
250 to 399 & $26.3 \%$ & $33.1 \%$ & $27.4 \%$ \\
400 to 499 & $9.4 \%$ & $12.4 \%$ & $9.9 \%$ \\
500 and up & $8.2 \%$ & $10.8 \%$ & $8.6 \%$ \\
\hline total & 36,865 & 7,152 & 44,017 \\
\hline Data: Short PFF & & & \\
\hline \hline
\end{tabular}

Table 4: Lis Pendens Filings by Monthly Payment

\begin{tabular}{lrr|r}
\hline \hline & no lis pendens & lis pendens & percent \\
\hline under 1,000 & $26.2 \%$ & $17.1 \%$ & $24.7 \%$ \\
1,000 to 1,499 & $14.6 \%$ & $12.3 \%$ & $14.2 \%$ \\
1,500 to 1,999 & $13.3 \%$ & $13.1 \%$ & $13.3 \%$ \\
2,000 to 2,499 & $13.3 \%$ & $15.5 \%$ & $13.7 \%$ \\
2,500 to 2,999 & $12.5 \%$ & $15.3 \%$ & $13.0 \%$ \\
3,000 to 3,999 & $13.0 \%$ & $17.6 \%$ & $13.7 \%$ \\
4,000 and up & $7.0 \%$ & $9.2 \%$ & $7.4 \%$ \\
\hline total & 36,865 & 7,152 & 44,017 \\
\hline Data: Short PFF & \multicolumn{3}{l}{} \\
\hline \hline
\end{tabular}

Finally, we wanted to know which of the loans that were in default progressed to foreclosure. Given the required 90-day period between filing a pre-foreclosure notice and the commencement of foreclosure proceedings (with a lis pendens filing) - we also had to restrict our attention to the loans that were filed prior to July 1, 2010 when preparing the Short PFF dataset.

Ideally, we would have chosen a later cut-off date, but the fact that Bank of America, JP Morgan Chase and GMAC Mortgage suspended foreclosure actions in late-September 2010 left us with little choice. As table 2 shows, there was a sharp drop in the number of loans that progressed to a lis pendens filing among loans which received a pre-foreclosure filing from July 2010 onward.

Another difficulty arose because the law which required mortgage servicers to file the pre-foreclosure filing notices did not explicitly require servicers to notify the NYSBD when the mortgage progressed to a lis pendens filing. The NYSBD strongly pressed servicers to update the filings however and most servicers complied.

Nonetheless, the suspension of foreclosure action by three of the largest servicers and the small degree of non-compliance with the NYSBD's two-step filing process convinced us that we should limit the 
Table 5: Lis Pendens Filings by Interest Rate

\begin{tabular}{lrr|r}
\hline \hline & no lis pendens & lis pendens & percent \\
\hline under 4.000 & $4.5 \%$ & $3.5 \%$ & $4.4 \%$ \\
4.000 to 4.999 & $4.3 \%$ & $4.1 \%$ & $4.3 \%$ \\
5.000 to 5.999 & $21.9 \%$ & $20.6 \%$ & $21.7 \%$ \\
6.000 to 6.999 & $34.4 \%$ & $39.6 \%$ & $35.3 \%$ \\
7.000 to 7.999 & $17.5 \%$ & $17.1 \%$ & $17.4 \%$ \\
8.000 to 9.999 & $12.1 \%$ & $11.1 \%$ & $11.9 \%$ \\
10.000 and up & $5.3 \%$ & $4.1 \%$ & $5.1 \%$ \\
\hline total & 36,865 & 7,152 & 44,017 \\
\hline Data: Short PFF & \multicolumn{3}{l}{} \\
\hline \hline
\end{tabular}

Table 6: Lis Pendens Filing by Loan Detail

\begin{tabular}{lrr|r}
\hline \hline & no lis pendens & lis pendens & total \\
\hline Fixed Rate & $84.4 \%$ & $15.6 \%$ & 35,117 \\
Adj. Rate & $82.6 \%$ & $17.4 \%$ & 7,309 \\
Pay. Op. Adj. Rate & $78.5 \%$ & $21.5 \%$ & 451 \\
Interest Only & $73.5 \%$ & $26.5 \%$ & 1,140 \\
\hline percent & $83.8 \%$ & $16.2 \%$ & 44,017 \\
\hline Data: Short PFF & \multicolumn{3}{|l}{} \\
\hline \hline
\end{tabular}

Short PFF dataset to loans submitted by servicers with at least 40 total filings and notified the NYSBD of a lis pendens filing on at least five percent of their loans. This step ensured that the information in the dataset would accurately reflect whether the loan progressed to a lis pendens filing or not.

\section{WHO ENTERS THE FORECLOSURE PROCESS?}

As mentioned in the introduction, the financial characteristics of a loan - such as the loan amount, monthly payment and whether the interest rate is fixed or adjustable - are the best predictors of progression from default to foreclosure.

For example, table 3 shows that - among borrowers who defaulted - 56 percent of the ones who entered the foreclosure process with a lis pendens filing borrowed more than $\$ 250,000$, whereas only 44 percent of the borrowers who did not go into foreclosure borrowed more than $\$ 250,000$.

Unfortunately, the PFF dataset does not have information on the loan-to-value ratio, so we do not know if and how far the recent collapse in home prices pushed these borrowers "underwater." Nonetheless, borrowers who took out larger loans would have had greater incentive to shift their losses onto their 
Table 7: Loan Detail by Year of Origination

\begin{tabular}{lrrrr|r}
\hline \hline & Fixed Rate & Adj. Rate (AR) & Pay. Option AR & Int. Only & total \\
\hline $1976-1989$ & $51.1 \%$ & $48.8 \%$ & $0.0 \%$ & $0.0 \%$ & 2,502 \\
$1990-1999$ & $89.1 \%$ & $10.8 \%$ & $0.1 \%$ & $0.0 \%$ & 13,692 \\
2000 & $90.6 \%$ & $9.2 \%$ & $0.0 \%$ & $0.1 \%$ & 2,414 \\
2001 & $93.9 \%$ & $6.0 \%$ & $0.0 \%$ & $0.0 \%$ & 4,390 \\
2002 & $93.2 \%$ & $6.6 \%$ & $0.0 \%$ & $0.1 \%$ & 7,470 \\
2003 & $92.4 \%$ & $7.3 \%$ & $0.1 \%$ & $0.2 \%$ & 16,706 \\
2004 & $83.5 \%$ & $15.3 \%$ & $0.4 \%$ & $0.8 \%$ & 18,669 \\
2005 & $73.8 \%$ & $22.5 \%$ & $1.2 \%$ & $2.5 \%$ & 28,506 \\
2006 & $69.0 \%$ & $26.2 \%$ & $1.9 \%$ & $2.9 \%$ & 35,947 \\
2007 & $77.7 \%$ & $17.3 \%$ & $1.8 \%$ & $3.2 \%$ & 31,771 \\
2008 & $93.9 \%$ & $4.6 \%$ & $0.6 \%$ & $0.9 \%$ & 16,019 \\
2009 & $97.6 \%$ & $2.3 \%$ & $0.0 \%$ & $0.2 \%$ & 6,957 \\
2010 & $92.4 \%$ & $7.3 \%$ & $0.0 \%$ & $0.3 \%$ & 1,323 \\
\hline percent & $81.2 \%$ & $16.1 \%$ & $1.0 \%$ & $1.7 \%$ & 186,366 \\
\hline Data: Full PFF & \multicolumn{5}{l}{} \\
\hline
\end{tabular}

Table 8: Lis Pendens Filings by Additional Borrower

\begin{tabular}{lrr|r}
\hline \hline & no lis pendens & lis pendens & total \\
\hline no co-borrower & $83.3 \%$ & $16.7 \%$ & 26,501 \\
co-borrower & $84.4 \%$ & $15.6 \%$ & 17,516 \\
\hline percent & $83.8 \%$ & $16.2 \%$ & 44,017 \\
\hline Data: Short PFF & \multicolumn{3}{|l}{} \\
\hline \hline
\end{tabular}

lenders by walking away from the loan if the drop in home prices left them with less equity (or negative equity).

Another possible reason why defaulted borrowers with large loan amounts are more likely to enter the foreclosure process is because - all else equal - they would have to make larger monthly payments. In fact, the distributions are very similar. Table 4 shows that, among borrowers who defaulted, 58 percent of the ones who entered the foreclosure process had a monthly payment of $\$ 2,000$ or more, whereas only 46 percent of the defaulted borrowers who did not progress to a lis pendens filing had a monthly payment in excess of $\$ 2,000$.

Surprisingly however, there is no clear relationship between a defaulted borrower's current interest rate and his/her chances of progressing to a lis pendens filing (as shown in table 5). The lack of a clear relationship may be attributable to the fact that we're looking at borrowers who have already defaulted. A high interest rate may be a good predictor of default, but not a good predictor of progression to a 
Table 9: Lis Pendens Filings by Amount of Delinquent Payment

\begin{tabular}{lrr|r}
\hline \hline & no lis pendens & lis pendens & percent \\
\hline under 1,000 & $4.1 \%$ & $0.9 \%$ & $3.5 \%$ \\
1,000 to 2,499 & $21.3 \%$ & $9.6 \%$ & $19.4 \%$ \\
2,500 to 4,999 & $26.0 \%$ & $19.2 \%$ & $24.9 \%$ \\
5,000 to 7,499 & $17.7 \%$ & $18.0 \%$ & $17.8 \%$ \\
7,500 to 9,999 & $8.5 \%$ & $10.8 \%$ & $8.9 \%$ \\
10,000 to 19,999 & $11.6 \%$ & $20.4 \%$ & $13.0 \%$ \\
20,000 to 49,999 & $7.1 \%$ & $15.0 \%$ & $8.4 \%$ \\
50,000 and up & $3.6 \%$ & $6.0 \%$ & $4.0 \%$ \\
\hline total & 36,865 & 7,152 & 44,017 \\
\hline Data: Short PFF & & \\
\hline \hline
\end{tabular}

Table 10: Lis Pendens Filings by Modification

\begin{tabular}{lrr|r}
\hline \hline & no lis pendens & lis pendens & total \\
\hline No modification & $83.9 \%$ & $16.1 \%$ & 34,962 \\
HAMP modification & $81.3 \%$ & $18.7 \%$ & 4,335 \\
Non-HAMP modification & $85.2 \%$ & $14.8 \%$ & 4,720 \\
\hline percent & $83.8 \%$ & $16.2 \%$ & 44,017 \\
\hline Data: Short PFF & & \\
\hline \hline
\end{tabular}

foreclosure filing.

The characteristic of interest rates that does predict progression from default to foreclosure is whether the interest rate is fixed or adjustable. Defaulted mortgages with adjustable interest rates progress to a lis pendens filing at slightly higher (but statistically significant) rate, while mortgages with payment option adjustable interest rates and interest only mortgages progress at a much higher rate (as shown in table 6).

Borrowers' difficulty in repaying loans with an adjustable rate mortgages also helps to explain why loans originated between 2004 and 2007 constitute 62 percent of all pre-foreclosure filings (as shown in table 1). Of the loans that went into default, those that were originated between 2004 and 2007 were more likely to be adjustable rate mortgages those originated in other years (as shown in table 7).

Interestingly however, adding a co-borrower to the loan did not necessarily reduce the chances that a loan would progress from default to foreclosure. As table 8 shows, the percentage of defaulted loans that progressed to a lis pendens filing was approximately the same for loans with a co-borrower and loans without a co-borrower (although the difference is statistically significant). The regression model in section 5 however suggests that loans with a co-borrower are less likely to progress to foreclosure.

Not surprisingly, defaulted borrowers who have to make a larger delinquent payment (i.e. the missed 
Table 11: Lis Pendens Filings by Length of Delinquency

\begin{tabular}{lrr|r}
\hline \hline & no lis pendens & lis pendens & percent \\
\hline less than 60 days & $58.0 \%$ & $31.8 \%$ & $53.7 \%$ \\
$61-90$ days & $15.1 \%$ & $16.3 \%$ & $15.3 \%$ \\
$91-120$ days & $6.5 \%$ & $9.9 \%$ & $7.0 \%$ \\
over 120 days & $20.5 \%$ & $42.0 \%$ & $24.0 \%$ \\
\hline total & 36,865 & 7,152 & 44,017 \\
\hline Data: Short PFF & & & \\
\hline \hline
\end{tabular}

Table 12: Modifications by Delinquency Length

\begin{tabular}{lrrr|r}
\hline \hline & No mod. & HAMP & non-HAMP & percent \\
\hline less than 60 days & $54.9 \%$ & $28.9 \%$ & $68.0 \%$ & $53.7 \%$ \\
$61-90$ days & $16.1 \%$ & $13.4 \%$ & $11.0 \%$ & $15.3 \%$ \\
$91-120$ days & $6.6 \%$ & $11.7 \%$ & $5.8 \%$ & $7.0 \%$ \\
over 120 days & $22.4 \%$ & $46.0 \%$ & $15.2 \%$ & $24.0 \%$ \\
\hline total & 34,962 & 4,335 & 4,720 & 44,017 \\
\hline Data: Short PFF & & \multicolumn{4}{l}{} \\
\hline \hline
\end{tabular}

monthly payments plus late fees, etc.) are more likely to progress from default to a lis pendens filing. As shown in table 9, 70 percent of defaulted borrowers who entered the foreclosure process owed $\$ 5,000$ or more, whereas only 49 percent of defaulted borrowers who did not progress to a lis pendens filing owed $\$ 5,000$ or more.

Finally, table 10 indicates that defaulted borrowers whose mortgages were modified via the Home Affordable Modification Program (HAMP) progress to a lis pendens filing at a higher rate than defaulted borrowers whose mortgages were either not modified at all or modified outside of the HAMP program.

This is not necessarily evidence that the HAMP program was unsuccessful however. Table 12 shows that mortgage servicers tended to send a pre-foreclosure filing notice (i.e. our indicator of default) to borrowers in the HAMP program at a much later stage of delinquency and table 11 shows that borrowers who receive a pre-foreclosure filing notice at a later stage of delinquency are far more likely to progress to a lis pendens filing.

Consequently, the high rates of progression to a lis pendens filing among defaulted borrowers in the HAMP program may be attributable to the late stage at which the NYSBD was notified of the default. In section 5, we'll revisit this question and show that defaulted borrowers in the HAMP program are much less likely to progress to a lis pendens filing than defaulted borrowers whose mortgages were either not modified at all or modified outside of the HAMP program. 
Table 13: Probit Models, dependent variable: Lis Pendens Filing

\begin{tabular}{|c|c|c|c|c|c|c|c|c|}
\hline \multirow{2}{*}{ In(Orig. Loan Amount) } & \multicolumn{2}{|c|}{ model \#1 } & \multicolumn{2}{|c|}{ model \#2 } & \multicolumn{2}{|c|}{ model \#3 } & \multicolumn{2}{|c|}{ model \#4 } \\
\hline & 0.0795 & $\star * \star *$ & & & 0.0592 & * & 0.0658 & * \\
\hline & $(0.0171)$ & & & & $(0.0275)$ & & $(0.0273)$ & \\
\hline \multirow[t]{2}{*}{ In(Amt. Delinq. Pay.) } & 0.0456 & $\star \star * *$ & 0.0424 & ** & 0.0411 & ** & 0.0386 & ** \\
\hline & $(0.0123)$ & & $(0.0131)$ & & $(0.0131)$ & & $(0.0131)$ & \\
\hline \multirow[t]{2}{*}{ In(Monthly Pay.) } & & & 0.0779 & $\star \star * *$ & 0.0283 & & 0.0267 & \\
\hline & & & $(0.0182)$ & & $(0.0294)$ & & $(0.0292)$ & \\
\hline \multirow[t]{2}{*}{ Delinq. $61-90$ days } & 0.3429 & 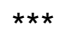 & 0.3444 & $\star * \star$ & 0.3443 & $\star \star \star *$ & 0.3483 & *** \\
\hline & $(0.0219)$ & & $(0.0220)$ & & $(0.0220)$ & & $(0.0220)$ & \\
\hline \multirow[t]{2}{*}{ Delinq. $91-120$ days } & 0.5230 & $\star * *$ & 0.5258 & $\star * \star *$ & 0.5260 & 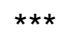 & 0.5315 & *** \\
\hline & $(0.0290)$ & & $(0.0291)$ & & $(0.0291)$ & & $(0.0291)$ & \\
\hline \multirow[t]{2}{*}{ Delinq. over 120 days } & 0.6607 & $\star * *$ & 0.6664 & $* * *$ & 0.6674 & *** & 0.6716 & *** \\
\hline & $(0.0253)$ & & $(0.0262)$ & & $(0.0262)$ & & $(0.0262)$ & \\
\hline \multirow[t]{2}{*}{ Current Int. Rate } & -0.0049 & & -0.0090 & & -0.0060 & & -0.0050 & \\
\hline & $(0.0049)$ & & $(0.0048)$ & & $(0.0050)$ & & $(0.0050)$ & \\
\hline \multirow[t]{2}{*}{ Adj. Rate } & 0.0190 & & 0.0242 & & 0.0199 & & & \\
\hline & $(0.0212)$ & & $(0.0211)$ & & $(0.0212)$ & & & \\
\hline \multirow[t]{2}{*}{ Pay. Op. Adj. Rate } & 0.0178 & & 0.0524 & & 0.0275 & & & \\
\hline & $(0.0708)$ & & $(0.0705)$ & & $(0.0715)$ & & & \\
\hline \multirow[t]{2}{*}{ Interest Only } & 0.1984 & $\star \star \star *$ & 0.2121 & $* * *$ & 0.2005 & $\star \star * *$ & & \\
\hline & $(0.0431)$ & & $(0.0428)$ & & $(0.0432)$ & & & \\
\hline \multirow[t]{2}{*}{ Not Fixed Rate Mortgage } & & & & & & & 0.0468 & * \\
\hline & & & & & & & $(0.0196)$ & \\
\hline \multirow[t]{2}{*}{ modified via HAMP } & -0.1350 & $\star \star \star ~$ & -0.1358 & 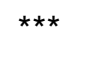 & -0.1358 & 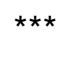 & -0.1404 & 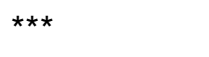 \\
\hline & $(0.0254)$ & & $(0.0255)$ & & $(0.0255)$ & & $(0.0254)$ & \\
\hline \multirow[t]{2}{*}{ modified, not HAMP } & 0.0058 & & 0.0090 & & 0.0063 & & 0.0050 & \\
\hline & $(0.0255)$ & & $(0.0255)$ & & $(0.0255)$ & & $(0.0255)$ & \\
\hline \multirow[t]{2}{*}{ Add'l Borrower on Loan } & -0.0678 & $\star \star \star *$ & -0.0678 & $\star * \star *$ & -0.0682 & 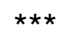 & -0.0711 & *** \\
\hline & $(0.0157)$ & & $(0.0157)$ & & $(0.0157)$ & & $(0.0157)$ & \\
\hline \multirow[t]{2}{*}{ Pay. inc. Escrow } & 0.1697 & *** & 0.1558 & $* * *$ & 0.1650 & *** & 0.1700 & *** \\
\hline & $(0.0200)$ & & $(0.0202)$ & & (0.0206) & & $(0.0204)$ & \\
\hline \multirow[t]{2}{*}{ Loan Investor Owned } & -0.1576 & *** & -0.1567 & $* * *$ & -0.1567 & *** & -0.1507 & *** \\
\hline & $(0.0186)$ & & $(0.0186)$ & & (0.0186) & & $(0.0185)$ & \\
\hline \multirow[t]{2}{*}{ In(No. Filings by Servicer) } & 0.0474 & *** & 0.0470 & $* * *$ & 0.0468 & *** & 0.0464 & *** \\
\hline & $(0.0067)$ & & $(0.0068)$ & & $(0.0068)$ & & $(0.0067)$ & \\
\hline AIC & 36,545 & & 36,549 & & 36,546 & & 36,558 & \\
\hline \multicolumn{9}{|c|}{${ }^{\star \star *} p<0.001,{ }^{* *} p<0.010,{ }^{*} p<0.050, \quad . p<0.100$} \\
\hline \multirow{2}{*}{\multicolumn{9}{|c|}{$\begin{array}{l}\text { Standard errors in parenthesis. All models also contain an intercept term and dummies for region and } \\
\text { year of origination. Those coefficients are not shown. }\end{array}$}} \\
\hline Data: Short PFF & & & & & & & & \\
\hline
\end{tabular}




\section{SIMPLE ECONOMETRIC MODEL}

With few exceptions, our findings that the financial characteristics of a home mortgages are good predictors of whether a loan progresses from default to foreclosure are not surprising. The rate of progression from default to a lis pendens filing is higher among defaulted borrowers who took out larger loans, who must make larger monthly payments and who face adjustable interest rates.

There were two puzzles however. One puzzle was why the rate of progression to a lis pendens filing bore no relation to the size of the interest rate. Another puzzle was why the difference in the rate of progression was so small between defaulted borrowers with and without a co-borrower.

Finally, we saw that a larger proportion of defaulted borrowers whose mortgages were modified via the HAMP program progressed to a lis pendens filing, but this difference may be attributable to the fact that their loans were reported the the NYSBD at a later stage of delinquency, so table 10 is not necessarily an indictment of the HAMP program.

In an attempt to resolve some of these puzzles, this section presents a very basic regression analysis in which we use probit models to estimate the probability that a defaulted loan will progress from default to a lis pendens filing. This allows us to examine the effect of one variable while holding others constant. The analysis presented here makes no effort to place the variables in a theoretical framework. Nor does it make much effort to check for robustness across specifications. Such work is left to future research.

Prior to discussing the probit models of the probability that a borrower will progress from default to a lis pendens filing, it is worth noting that the overall rate at which loans in the Short PFF dataset progressed from default to a lis pendens filing is only about 16 percent. The low overall rate is attributable to two factors. First, table 11 shows that about half of them were delinquent for less than 60 days when the servicer filed the pre-foreclosure filing notice. These loans were less likely to progress to a lis pendens filing than those that had been deliquent for a longer period of time. Second, table 9 shows that about 48 percent of the borrowers who defaulted owed less than $\$ 5,000$. Not surprisingly, their loans were less likely to progress to a lis pendens filing than borrowers who owed more.

In choosing variables to include in the probit models, we took note of the high degree of correlation among the original loan amount, the monthly payment and the amount of delinquent payment. Consequently, we excluded the original loan amount and the monthly payment from two of the regression models. This helps show that the original loan amount, the monthly payment and the amount of delinquent payment are all good predictors of progression from default to foreclosure.

Interestingly however, the regression results suggest that - after controlling for other factors - defaulted borrowers with an adjustable rate mortgage or a payment option adjustable rate mortgage do not progress to foreclosure at a significantly higher rate than defaulted borrowers with a fixed rate mortgage. However, the difference between defaulted borrowers with a fixed rate mortgage and defaulted borrowers with an interest only loan is statistically significant. Those with an interest only loan are more likely to progress to foreclosure.

The regression results also help resolve the two puzzles mentioned above. A defaulted borrower's probability of progressing to foreclosure is positively correlated with the interest rate that he/she pays on the loan and the coefficient is statistically significant.

The probit models also help resolve the puzzle that we observed in table 8 - the finding that loans 
with a co-borrower progress to foreclosure at approximately the same rate as those without co-borrower. After controlling for other factors, defaulted loans with a co-borrower are negatively correlated with the probability of progression to a lis pendens filing.

Finally, the regression results indicate that the HAMP program was more successful than critics have argued. In the Short PFF dataset, defaulted borrowers with a HAMP-modified mortgage progressed to foreclosure at a higher rate, but the regression results suggest that this difference is attributable to the fact that they received a pre-foreclosure filing notice at a later stage of delinquency (as we saw in tables 10, 11 and 12). After controlling for other factors, defaulted borrowers with a HAMP-modified mortgage were significantly less likely to progress to foreclosure than their counterparts without a modification or with a non-HAMP modification.

\section{CONCLUSION}

Given our finding that large loan original amounts and high monthly payments are good predictors that a defaulted borrower will progress to a lis pendens filing, one could conclude that reducing the principal balances on home mortgages would substantially reduce the foreclosure rate.

Reducing principal balances may be impractical, however. In cases where borrowers have negative equity, this would require lenders to absorb potentially very large losses on their portfolio of mortgages. Secondly, an across-the-board reduction in principal balance would benefit a large number of borrowers who otherwise would not default on their mortgages.

If the modifications were well-structured however, so that the balance-sheet effect of the lower probability of progressing to foreclosure offsets the losses that the lender would suffer by taking the loan to foreclosure, then reducing principal balances might have the desired effect of reducing losses in the mortgage industry.

Assuming that such a structure could be found, it may depend on information that the NYSBD's preforeclosure filing data does not contain, such as the borrower's income or the purpose of the loan. The publicly-available data from the Home Mortgage Disclosure Act (HMDA) does contain this information however, so in future work, we plan to incorporate the information from the HMDA dataset into the Short PFF dataset to see how those factors affect a borrower's probability of progressing from default to foreclosure and explore other options that may help the industry reduce its losses. In that analysis, we will also attempt to quantify the savings that the industry would achieve from such modifications.

\section{ACKNOWLEDGEMENTS}

We would like to thank the New York State Banking Department for making the Pre-Foreclosure Filing data available to us and for supporting our research. The views expressed in this paper are our own opinions and do not necessarily reflect the opinions of the New York State Banking Department. 


\section{REFERENCES}

CoreLogic. "US Housing and Mortgage Trends", May 2011. URL http://www.corelogic.com/ about-us/researchtrends/asset_upload_file722_8290.pdf.

E. Doviak and S. MacDonald. "Who Defaults on their Home Mortgage?". 24 Sept. 2011.

S. Humphries. "No Respite From Housing Recession in First Quarter". Zillow Real Estate Research, 8 May 2011. URL http://www.zillow.com/blog/research/2011/05/08/ no-respite-from-housing-recession-in-first-quarter/.

B. Naylor. "Homeowners Rescue Program Shows Slim Benefits". National Public Radio, 3 Feb. 2009. URL http: //www.npr.org/templates/story/story . php? storyId=100163398.

New York State Banking Department. "2009 Mortgage Foreclosure Law - Overview”, 2009. URL http: //www.banking.state.ny.us/mfl2009.htm.

RealtyTrac. "Foreclosure Activity Continues Free-Fall in May". RealtyTrac press release, 16 June 2011. URL http://www.realtytrac.com/content/news-and-opinion/ foreclosure-activity-continues-free-fall-in-may-6651.

State Foreclosure Prevention Working Group. "Redefault Rates Improve for Recent Loan Modifications". Memorandum on Loan Modification Performance, Aug. 2010. URL http://www.csbs.org/ regulatory/Documents/SFPWG/DataReportAug2010.pdf.

U.S. Dept. of the Treasury. "Final Notice of Proposed New Privacy Act System of Records for the Home Affordable Modification Program". Federal Register, 74(207):55621-55623, 28 Oct. 2009. URL http: //edocket.access.gpo.gov/2009/pdf/E9-25897.pdf.

U.S. Dept. of the Treasury. "Making Home Affordable Program Performance Report Through June 2011", 5 Aug. 2011. URL http://www.treasury.gov/initiatives/financial-stability/results/ MHA-Reports/Documents/June 202011\%20MHA 20Report\%20F INAL. pdf.

U.S. Office of the Comptroller of the Currency. "FHA HOPE for Homeowners Program". Community Developments, Apr. 2010. URL http://www.occ.gov/static/community-affairs/fact-sheets/ FHA_HOPE_for_Homeowners_Program_ES.pdf. 
